\title{
NPHS1 and NPHS2 Gene Mutations in Chinese Children With Sporadic Nephrotic Syndrome
}

\author{
JIANHUA MAO, YANG ZHANG, LIZHONG DU, YUWEN DAI, WEIZHONG GU, AI'MIN LIU, SHIQIANG SHANG, \\ AND LI LIANG
}

\begin{abstract}
Department of Nephrology [J.M., L.D., Y.D., W.G., A.L.S.S., L.L.], Zhejiang University School of Medicine, Children's Hospital, Hangzhou 310006, Zhejiang Province, P.R.China.; Department of Epidemiology [Y.Z.], Zhejiang University School of Medicine, Hangzhou 310031, Zhejiang Province, P.R. China.
\end{abstract}

\begin{abstract}
Recent discoveries indicate that the molecules in glomerular podocytes and slit diaphragms may play an important role in the development of proteinuria and nephrotic syndrome. Mutational analyses of NPHS1 and NPHS2 were performed to verify this hypothesis in sporadic nephrotic syndrome (NS) patients. Clinical characteristics and DNA samples were collected from 38 Chinese children with sporadic steroid-sensitive NS, 22 with steroid-resistant NS and 30 controls. Direct sequencing was performed after PCR amplification of all 29 and 8 exons of the NPHS1 and NPHS2 genes, respectively. In $N P H S 1,4$ patients had heterozygous missense mutations leading to amino acid substitutions (R800C, Q453R). Furthermore, 3 known single nucleotide polymorphism (SNP) were found (T741T, V763V, S1105S). In NPHS2, 3 patients had novel heterozygous allelic variants leading to amino acid substitutions (S206I, E188D), while 1 patient was found to carry a novel nonsense mutation leading to a truncated protein product (Glu237STOP). Two known polymorphisms were also found (A318A, L346L). The results demonstrate that NPHS1 and NPHS2 mutations are also present in Chinese sporadic NS patients, suggesting that genetic changes of nephrin and podocin may play pathogenetic roles in some patients with sporadic steroid resistant NS. (Pediatr Res 61: 117-122, 2007)
\end{abstract}

$\mathrm{N}^{\mathrm{e}}$ ephrotic syndrome (NS), defined as the association of proteinuria, hypoalbuminemia, edema and hyperlipidemia, constitutes one of the most common diagnoses made in pediatric nephrology and is emerging as a leading cause of uremia. For decades, NS has been separated into two broad categories based upon its response to standard steroid therapy: steroid-sensitive nephrotic syndrome (SSNS) and steroidresistant nephrotic syndrome (SRNS) $(1,2)$. About $20 \%$ of all children with sporadic NS do not respond to steroid treatment. Renal histology reveals focal segmental glomerulosclerosis (FSGS), minimal change nephrotic syndrome (MCNS) and mesangioproliferative glomerulonephritis (MsPGN) in 75\%, $20 \%$ and $5 \%$ of the SRNS patients, respectively (3). The management of steroid-resistant nephrotic syndrome continues to pose a therapeutic challenge to nephrologists.

Received March 29, 2006; accepted September 5, 2006

Correspondence: Yang Zhang, Ph.D., Zhejiang University School of Medicine, Department of Epidemiology, Hangzhou 310031, Zhejiang Province, P.R. China; e-mail: Zhangy@zju.edu.cn

Supported by Zhejiang Provincial Natural Science Foundation of China, No: 302656 \& No: Y204148, Zhejiang provincial Healthy Science Foundation, No: 2004QN014, and Zhejiang provincial Educational Foundation, No: 20040233.

DOI: $10.1203 / 01 . p d r .0000250041 .19306 .3 d$
Although loss of glomerular selectivity for albumin is common to all types of NS, the related pathogenesis has been elusive despite decades of studies into its renal histology and protein biochemistry. It appears to be a heterogeneous clinical condition characterized by histologic variants and different genetic backgrounds. Many different and seemingly unrelated genomic and molecular markers correlate with the NS disease course, again supporting the molecular heterogeneic nature of the NS group of disorders. These markers can be divided into two categories: immune-related and structural. In recent years, advances in molecular genetics of familial NS have led to the discovery of several podocyte specific genes. Identification of these candidate genes for monogenic forms of SRNS indicates the importance of genetic factors in the pathogenesis of NS.

Many exciting advances have increased our understanding of genetic causes of familial SRNS recently. Mutations in the NPHS1 gene encoding nephrin, the NPHS2 gene encoding podocin, the ACTN-4 gene encoding $\alpha$ - actinin- 4 , the WT1 gene coding Wilm's Tumor 1 and TRPC6 gene coding the ion-channel protein transient receptor potential cation channel 6 have been identified $(4-8)$. However, these mutations in these genes do not account for all cases of familial FSGS, especially for nonfamilial SRNS.

Several studies have indicated that nephrin, a $136 \mathrm{kD}$ transmembrane protein with a large extracellular portion with eight immunoglobulin-like domains, is crucial for the structure of slit diaphragm (SD). Mutation in the NPHS1 gene is responsible for the congenital nephrotic syndrome of the Finnish type (CNF), which can cause lethal proteinuria at birth and lack of the SD. Meanwhile, the non-Finnish NS patients have different mutations, and more than 60 mutations in the NPHS1 genes have been described (9-11).

Podocin is another important molecule located at the slit diaphragm. It is encoded by the NPHS2 gene, mutation of which can cause autosomal recessive steroid-resistant nephrotic syndrome. Podocin is expressed in the podocyte foot

\footnotetext{
Abbreviations: CNF, congenital nephrotic syndrome of the Finnish type; ESRD, end-stage renal disease; FSGS, focal segmental glomerulosclerosis; IgAN, IgA nephropathy; MCNS, minimal change nephrotic syndrome; MsPGN, mesangial proliferative glomerulonephritis; NS, nephrotic syndrome; SD, slit diaphragm; SRNS, steroid-resistant nephrotic syndrome; SSNS, steroid-sensitive nephrotic syndrome
} 
Table 1. General features and clinical details in 60 Chinese children with sporadic nephrotic syndrome

\begin{tabular}{ccccccc}
\hline & \multicolumn{2}{c}{$\begin{array}{c}\text { Mean age } \\
\text { at onset }\end{array}$} & Male/female & Hypertension & Renal function & Follow-up \\
& $n$ & 8.2 & $22 / 16$ & Normal 35, Abnormal 3 & Normal 36, Transient abnormal 2 & MCNS, 4; FSGS, 1; IgAN, 2 \\
duration (year)
\end{tabular}

process cell membrane at the insertion site of the SD as shown by immunoelectron microscopy, which proposes that podocin might be important for maintaining the integrity of the SD. Since the identification of the NPHS2, different groups have demonstrated that mutations in the NPHS2 gene represent a frequent cause of SRNS, occurring in $20-30 \%$ of the sporadic cases of SRNS (12-14).

The role of nephrin and podocin in children with sporadic nephrotic syndrome is not clearly known till now. Some studies reported of NPHS1 gene mutations in patients with MCNS $(9,15)$. Also, altered expression of nephrin and podocin has been reported in MCNS and FSGS patients. We also identified recently that the expression of nephrin and CD2associated protein (CD2AP) were significantly reduced at protein level in nephrotic patients with MCNS and IgA nephropathy (IgAN), though no significant reduction in podocin expression was found compared with the controls. This prompted us to investigate whether mutations in the NPHSI and NPHS2 genes lie behind Chinese patients with sporadic nephrotic syndrome. Specifically, we performed mutational analysis for all 29 and 8 exons of NPHS1 and NPHS2, respectively, among 38 patients with SSNS, 22 patients with SRNS and 30 controls. We identified 8 SRNS patients carried missense and nonsense mutations in the NPHS1 or NPHS2 genes. Therefore, mutational analysis of NPHS1 and NPHS2 among patients with sporadic nephrotic syndrome might be helpful for predicting their response to standard steroid treatment during the early stage of onset, and will also be valuable for forecasting their prognosis after onset.

\section{MATERIALS AND METHODS}

Patients and controls. The study was approved by The Ethic Committee of Children's Hospital of Medical College, Zhejiang University. Informed consent was obtained from all the parents of the patients and controls, or from patients and controls themselves, depending on their perceptive capability. The study group consisted of 60 children who had been diagnosed as sporadic nephrotic syndrome in Children's Hospital of Medical College, Zhejiang University from 2001 to 2004 . Clinical data including the medication, number of relapse and laboratory findings were also recorded. A family history was taken and the absence of the nephrotic syndrome in the first-degree relatives was required. Controls included 30 children with no personal or family history of a kidney disease. Both the study subjects and the control subjects are of Mongolian origin. Exclusion criteria were low $\mathrm{C}_{3}$-complement; postinfectious glomerulonephritis; and systemic diseases such as lupus erythematodes, diabetes, amyloidosis, vasculitis, Schönlein-Henoch purpura nephritis, metabolic or toxic nephritis, hepatitis B, or hereditary glomerular diseases.

Definitions and treatment. Sporadic nephrotic syndrome was defined as heavy proteinuria (urine protein exceeding $40 \mathrm{mg} / \mathrm{m}^{2} / \mathrm{h}$ ), and hypoalbuminemia (serum albumin $\leq 25 \mathrm{~g} / \mathrm{L}$ ) without familial history of proteinuria. All patients received a standard treatment with daily corticosteroid (prednisone) at a dose of $2 \mathrm{mg} / \mathrm{kg} / \mathrm{d}$ (maximum $60 \mathrm{mg} / \mathrm{d}$ ) for $4 \mathrm{wk}$ and were then switched to alternate day therapy. The patients who respond to initial treatment after 4 wk of the daily steroid treatment as complete resolution of proteinuria and edema were defined as steroid-sensitive. If no improvement was observed, the patients were defined as SRNS. Patients with late steroid resistance were excluded in this study.
Hypertension was defined as blood pressure higher than $95^{\text {th }}$ percentile for age according to data from Task Force Report on High Blood Pressure in Children and Adolescents. Hematuria was defined as a dipstick reading of $1+$ or more for blood or as more than 3 red blood cells per high-power field in urine sediment. Estimated GFR (GFR) was calculated by the Schwartz formula: GFR $=\mathrm{k} \times$ height $(\mathrm{cm}) /$ plasma creatinine $(\mathrm{mg} / \mathrm{dL})$, where $\mathrm{k}$ is 0.45 for infants ( $\leq 18 \mathrm{mo}$ of age), 0.55 for older children and adolescent girls, and 0.7 for adolescent boys over 13 y of age. Decreased kidney function was defined as GFR $\leq 90 \mathrm{~mL} / \mathrm{min} / 1.73 \mathrm{~m}$ (2), CRF as GFR $\leq 60 \mathrm{~mL} / \mathrm{min} / 1.73 \mathrm{~m}$ (2), and end-stage renal disease (ESRD) as GFR $\leq 15 \mathrm{~mL} / \mathrm{min} / 1.73 \mathrm{~m}$ (2).

DNA samples. Peripheral blood samples were collected from 38 Chinese sporadic SSNS patients, 22 SRNS patients and 30 controls in Hangzhou area of Zhejiang province of P. R. China. DNA preparation Kit (Takara, Japan) was used to purify DNA from a $150-\mu \mathrm{L}$ EDTA-treated blood samples.

PCR conditions. Genomic DNA (50 ng) was subjected to 35-40 cycles of PCR amplification in a volume of $50 \mu \mathrm{L}$ consisting of $2 \mu \mathrm{L} 5 \mathrm{pmol} / \mathrm{L}$ sense primer, $2 \mu \mathrm{L} 5 \mathrm{pmol} / \mathrm{L}$ antisense primer, $1.5-3.5 \mathrm{mM} \mathrm{MgCl} 2,100 \mathrm{mM}$ dNTPs, and 2.5 U Taq polymerase (Perkin-Elmer Applied Biosystems, Foster City, CA). DNA was denatured at $95^{\circ} \mathrm{C}$ for $10 \mathrm{~min}$, followed by $35-40$ cycles of denaturing for $1 \mathrm{~min}$ at $95^{\circ} \mathrm{C}$, annealing for $45 \mathrm{~s}$ at $55-68^{\circ} \mathrm{C}$, extension for $45 \mathrm{~s}$ at $72^{\circ} \mathrm{C}$, and final extension of $7 \mathrm{~min}$ at $72^{\circ} \mathrm{C}$ in a thermocycler (GeneAmp PCR system 2400, Perkin-Elmer, CA).

Detection of genomic mutation of NPHS1 and NPHS2 The primers were designed on the basis of previously published information regarding intronexon boundaries $(4,5)$. The PCR products were purified with the QIA Quick PCR Purification Kit (Qiagen, Hilden, Germany). The purified products were subjected to cycle-sequenced with Big-Dye terminators (Applied Biosystems, Foster City, CA, USA). The cycle sequence product was analyzed with an automated sequencer (ABI Prism 310 Genetic Analyzer, Applied Biosystems).

All mutations were confirmed by sequencing the complementary strand. Known single nucleotide polymorphisms within the primer sequences were avoided (http://genome.ucsc.edu/), because single nucleotide variants within the primer sequence can suppress amplification of one of the two alleles of the amplified product. To rule out polymorphisms, 30 healthy control individuals (age and ethnic background similar to the patients) were checked for novel mutations by direct sequencing.

Statistical analysis. $\chi^{2}$ test were used to analyze the difference of genotypic and allelic frequencies between NS patients and controls by SPSS software. $p<0.05$ was viewed as statistically significant.

\section{RESULTS}

Clinical data of the patients with SSNS and SRNS. The clinical data are listed in Table 1. In 22 SRNS patients, renal insufficiency was seen in 6 patients. By renal biopsy, 6

Table 2. Amino acid substitutions and polymorphisms of the NPHS1 gene in 38 SSNS patients, 22 SRNS and 30 controls subjects

\begin{tabular}{|c|c|c|c|c|c|}
\hline \multirow{2}{*}{$\begin{array}{l}\text { Exon/ } \\
\text { intron }\end{array}$} & \multirow{2}{*}{$\begin{array}{l}\text { Nucleotide } \\
\text { change }\end{array}$} & \multirow{2}{*}{$\begin{array}{l}\text { Effect on } \\
\text { protein }\end{array}$} & \multicolumn{2}{|c|}{$\begin{array}{c}\text { No. of changes } \\
\text { per Alleles }\end{array}$} & \multirow[b]{2}{*}{ Comment } \\
\hline & & & NS & Control & \\
\hline Intron & $7906 \mathrm{G} \rightarrow \mathrm{A}$ & Unknown & $4 / 60$ & $1 / 30$ & Homozygous \\
\hline Intron & $7906 \mathrm{G} \rightarrow \mathrm{A}$ & Unknown & $5 / 60$ & $2 / 30$ & Heterozygous \\
\hline Intron & $7892 \mathrm{C} \rightarrow \mathrm{T}$ & Unknown & $2 / 60$ & $1 / 30$ & Heterozygous \\
\hline Exon11 & $1358 \mathrm{~A} \rightarrow \mathrm{G}$ & Q453R & $1 / 60$ & $0 / 30$ & Heterozygous \\
\hline Exon17 & $2223 \mathrm{C} \rightarrow \mathrm{T}$ & $\mathrm{T} 741 \mathrm{~T}$ & $9 / 60$ & $4 / 30$ & Heterozygous \\
\hline Exon17 & $2289 \mathrm{C} \rightarrow \mathrm{T}$ & V763V & $6 / 60$ & $2 / 30$ & Homozygous \\
\hline Exon17 & $2289 \mathrm{C} \rightarrow \mathrm{T}$ & V763V & $10 / 60$ & $3 / 30$ & Heterozygous \\
\hline Exon18 & $2398 \mathrm{C} \rightarrow \mathrm{T}$ & $\mathrm{R} 800 \mathrm{C}$ & $3 / 60$ & $0 / 30$ & Heterozygous \\
\hline Exon26 & $3315 \mathrm{G} \rightarrow \mathrm{A}$ & S1105S & $2 / 60$ & $2 / 30$ & Homozygous \\
\hline
\end{tabular}




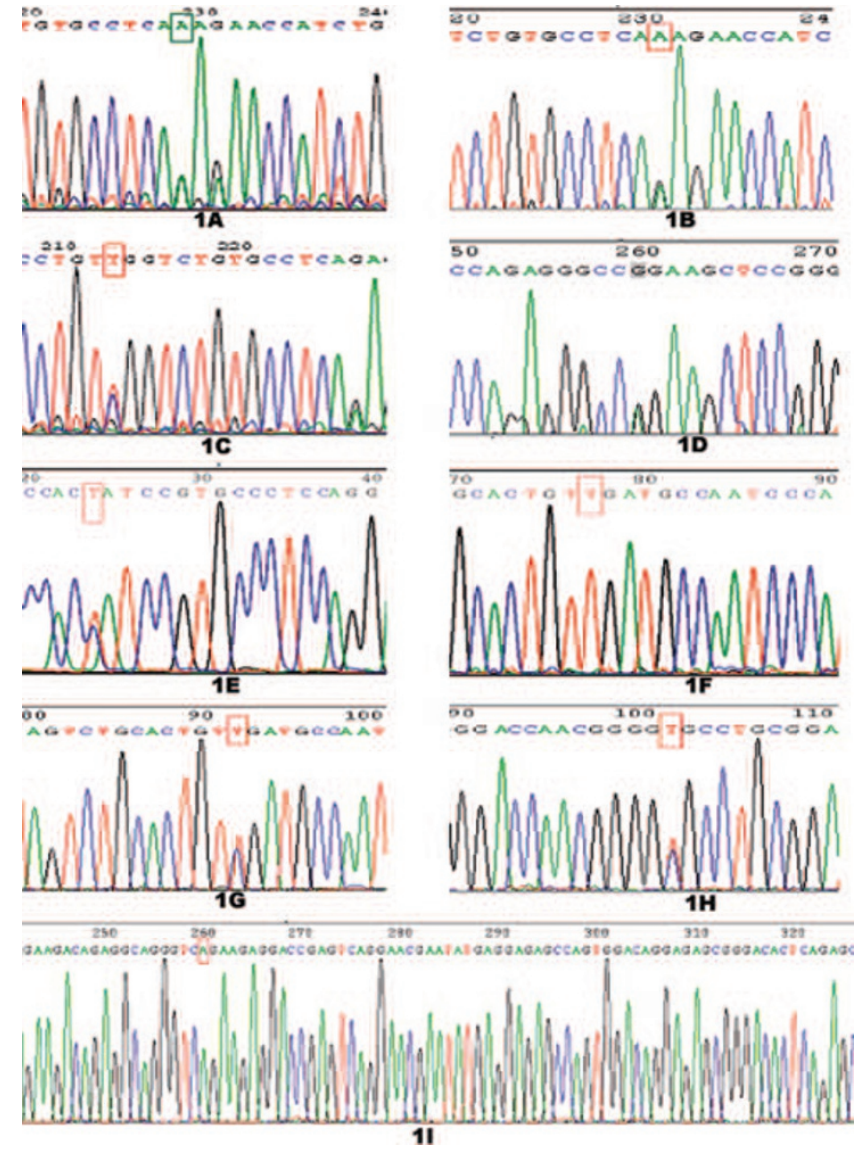

Figure 1. NPHS1 mutation: $(A)$ intron, $7906 \mathrm{G} \rightarrow \mathrm{A}$, homozygous; $(B)$ intron, $7906 \mathrm{G} \rightarrow \mathrm{A}$, heterozygous; $(C)$ intron, $7892 \mathrm{C} \rightarrow \mathrm{T}$, heterozygous; $(D)$ exon11, $1358 \mathrm{~A} \rightarrow \mathrm{G}$ 'Q453R'heterozygous; $(E)$ exon17, 2223C $\rightarrow$ T'T741T'heterozygous; $(F)$ exon17, $2289 \mathrm{C} \rightarrow \mathrm{T}^{\prime} \mathrm{V} 763 \mathrm{~V}$, homozygous; $(G)$ exon17, $2289 \mathrm{C} \rightarrow \mathrm{T}^{\prime} \mathrm{V} 763 \mathrm{~V}$, heterozygous; $(H)$ exon18, 2398C $\rightarrow \mathrm{T}$, R800C, heterozygous; $(I)$ Exon26, 3315 $\mathrm{G} \rightarrow \mathrm{A}$ 'S1105S'homozygous.

patients showed evidence of MCNS, 5 of FSGS, 2 of IgAN and 1 of mesangial proliferative glomerulonephritis (MsPGN). The mean follow-up duration in 22 SRNS was $3.7 \mathrm{y}$.

Allelic variants of NPHS1. None of the patients had the Fin-major mutation in the exon 2 or the Fin-minor mutation in the exon 26. A total of 9 sequence variants were observed in 4 exons and 3 introns, as summarized in Table 2 and listed from Fig. 1A-I. To examine the significance of these mutations, the same exons were also sequenced from 30 control subjects, and the results were compared with the published data and database (dbSNP, SNPper).

Three of 9 nucleotide changes (T741T heterozygous, V763V heterozygous and homozygous, S1105S homozygous) as known polymorphic variants (SNP) (Table 2 and Fig. $1 E-G, I$ ) were found in 9,16 and 2 patients respectively, and none of them caused an amino acid substitution. Nucleotide changes were found particularly at exon 17 , but also at exon 18 and 26.

Three patients were found to have a $2398 \mathrm{C}>\mathrm{T}$ nucleotide change resulting heterozygous R800C (Fig. 1H) transition leading to amino acid substitution of arginine by cysteine in Ig-7 domain of nephrin. The onset of proteinuria in patients with this mutation occurred, respectively, at age 8.4, 7.3 and $6.5 \mathrm{y}$ (Table 3). All of them are steroid-resistant. Among them, 1 patient carries also the T741T polymorphism. However, no differences were found in symptom severity and response to drug therapy between this patient and other 2 patients with the R800C mutation.

One patient was detected as carrying a novel $1358 \mathrm{~A} \geq \mathrm{G}$ mutation (heterozygous) in the exon 11 leading to the substitution of Q453 with arginine (Fig. 1D). He is a young boy with no history of renal disease, with poor response to the standard steroid treatment and abnormal renal dysfunction $2.7 \mathrm{y}$ after onset. Moreover, a renal biopsy showed evidence of FSGS. The same mutation was not detected in his parents at all (Table 3).

Allelic variants of NPHS2. A total of 5 sequence variants were observed in 2 exons, as summarized in Table 4 and Fig. $2 A-E$. To examine the significance of these mutations, the same exons were also sequenced from 30 control subjects, and the results were compared with the published data and database (dbSNP, SNPper).

A novel homozygous nonsense mutation in NPHS2, E237X (709G $>\mathrm{T}$ in the exon 5) was detected in one patient (Table 3, Fig. 2E). This nucleotide change introduces a stop codon (TAG), leading to a truncated protein product. This patient is a 6.8 -y-old boy with no family history of proteinuria and renal disease. He was diagnosed as having nephrotic syndrome 1.2 $\mathrm{y}$ ago. His condition has deteriorated even after the treatment with corticosteroid and cyclosporine $\mathrm{A}$, and presently his renal function is abnormal (serum creatinine $219.6 \mu \mathrm{M}$ ). The par-

Table 3. Clinical data of patients carrying NPHS1 and/or NPHS2 mutation

\begin{tabular}{|c|c|c|c|c|c|c|c|c|c|c|}
\hline \multirow[b]{2}{*}{ Patient } & \multirow[b]{2}{*}{ Gender } & \multirow{2}{*}{$\begin{array}{c}\text { Age } \\
\text { (years) }\end{array}$} & \multirow{2}{*}{$\begin{array}{c}\text { Age at onset } \\
\text { (years) }\end{array}$} & \multirow{2}{*}{$\begin{array}{c}\text { Proteinuria } \\
(\mathrm{g} / 24 \mathrm{~h})\end{array}$} & \multirow{2}{*}{$\begin{array}{l}\text { Serum creatinine } \\
\quad(\mu \mathrm{mol} / \mathrm{L})\end{array}$} & \multirow{2}{*}{$\begin{array}{c}\text { BUN } \\
(\mathrm{mmol} / \mathrm{L})\end{array}$} & \multirow[b]{2}{*}{$\mathrm{C}_{3} \mathrm{mg} / \mathrm{dl}$} & \multirow[b]{2}{*}{ Renal biopsy } & \multicolumn{2}{|c|}{ Mutation } \\
\hline & & & & & & & & & NPHS1 & NPHS2 \\
\hline 1 & M & 11.2 & 8.5 & 3.52 & 112.2 & 8.46 & 90.3 & FSGS & Q453R & A318A \\
\hline 3 & $\mathrm{~F}$ & 8.2 & 7.3 & 3.84 & 105.6 & 6.67 & 114.8 & ND & R800CandT741T & \\
\hline 4 & M & 8.7 & 6.5 & 7.29 & 98.2 & 5.81 & 91.7 & MCNS & $\mathrm{R} 800 \mathrm{C}$ & \\
\hline 5 & M & 14.8 & 6.8 & 9.23 & 120.4 & 9.53 & 143.6 & FSGS & S1105S & S206I \\
\hline 8 & M & 6.8 & 5.6 & 4.10 & 219.6 & 15.43 & 125.6 & FSGS & & Glu237STOP \\
\hline 9 & $\mathrm{~F}$ & 7.8 & 6.7 & 3.25 & 110.7 & 6.54 & 113.7 & ND & V763V & \\
\hline
\end{tabular}

BUN, serum urea nitrogen; C3, complement C3; MCNS, minimal change nephrotic syndrome; FSGS, focal segmental glomerular sclerosis; MsPGN, mesangial proliferative glomerulonephritis. 
Table 4. Amino acid substitutions and polymorphisms of the NPHS2 gene in 38 SSNS patients, 22 SRNS and 30 controls subjects

\begin{tabular}{|c|c|c|c|c|c|}
\hline \multirow{2}{*}{$\begin{array}{l}\text { Exon/ } \\
\text { Intron }\end{array}$} & \multirow{2}{*}{$\begin{array}{l}\text { Nucleotide } \\
\text { change }\end{array}$} & \multirow{2}{*}{$\begin{array}{l}\text { Effect on } \\
\text { protein }\end{array}$} & \multicolumn{2}{|c|}{$\begin{array}{l}\text { No. of changes } \\
\text { per Alleles }\end{array}$} & \multirow[b]{2}{*}{ Comment } \\
\hline & & & NS & Control & \\
\hline Exon8 & $1038 \mathrm{~A} \rightarrow \mathrm{G}$ & L346L & $7 / 60$ & $4 / 30$ & Heterozygous, known polymorphism, no amino acid change \\
\hline Exon5 & $564 \mathrm{G} \rightarrow \mathrm{T}$ & E188D & $1 / 60$ & $0 / 30$ & Homozygous \\
\hline Exon5 & $617 \mathrm{G} \rightarrow \mathrm{T}$ & S206I & $2 / 60$ & $0 / 30$ & Heterozygous \\
\hline
\end{tabular}

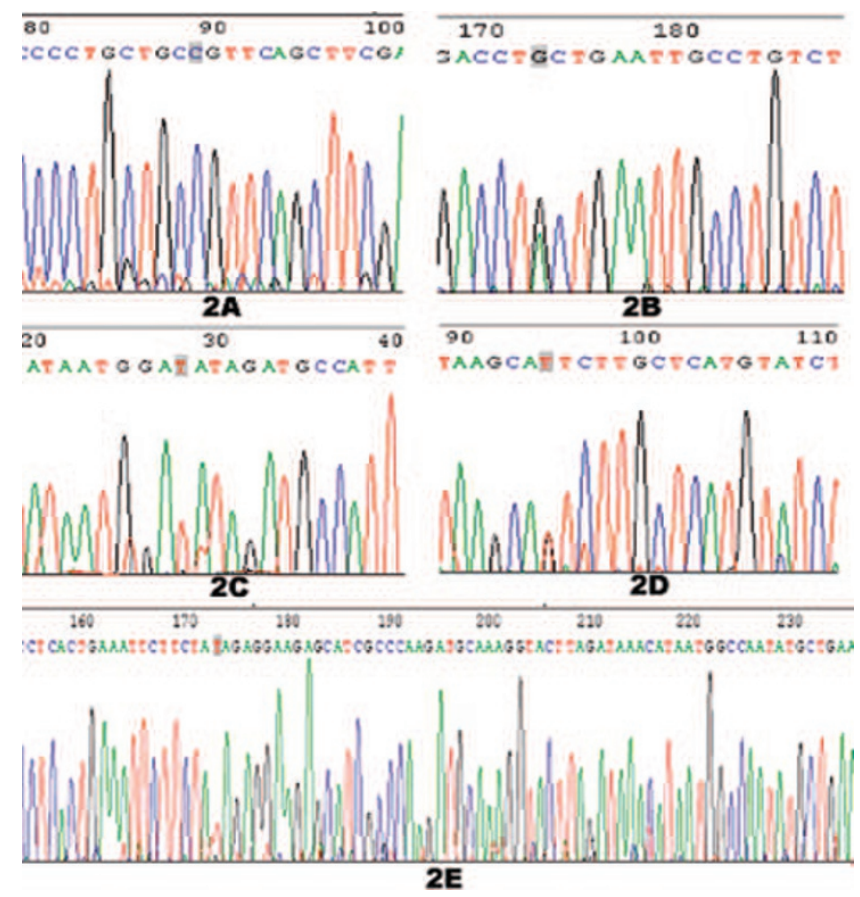

Figure 2. NPHS2 mutation: $(A)$ Exon8, 954T $\rightarrow$ C'A318A'homozygous; $(B)$ Exon 8, 1038A $\rightarrow$ G'L346L'heterozygous; ( $C$ Exon 5, 564G $\rightarrow$ T'E188D'homozygous; $(D)$ Exon 5, 617G $\rightarrow$ T'S206I, heterozygous; $(E)$ Exon $5,709 \mathrm{G} \rightarrow$ T' Glu237STOP, homozygous.

ents of the patient do not carry the identity mutation in NPHS2 or NPHS1.

Two novel missense mutations in the NPHS2 gene, E188D $(564 \mathrm{G}>\mathrm{T}$ in the exon 5, homozygous, Fig. 2C) and S206I $(617 \mathrm{G}>\mathrm{T}$ in the exon 5, heterozygous, Fig. $2 D)$ were detected in 3 patients. The patient carrying the $564 \mathrm{G}>\mathrm{T}$ mutation is a girl without family history of renal disease. At the time of the onset she was $8.1 \mathrm{y}$ old. She has received the standard steroid and cyclosporine A treatment and her renal function remains normal $2.5 \mathrm{y}$ after the onset. Her mother is healthy though carrying same heterozygous mutation. This mutation was not identified in the father of the patient. One patient carrying the $617 \mathrm{G}>\mathrm{T}$ mutation is a boy with no history of renal disease. At the age of 6.8 years he was diagnosed as having nephrotic syndrome. He is resistant to the standard steroid therapy and his renal function is abnormal with the serum creatinine concentration of $120.4 \mu \mathrm{M}$ and BUN of $9.53 \mathrm{mM}$. The parents were not consanguineous. This mutation was not identified in the parents of the patient. Another patient carrying the same $617 \mathrm{G}>\mathrm{T}$ mutation is a 9.2-y-old girl. Her renal function remains normal.

A single nucleotide polymorphisms of $954 \mathrm{~T} \geq \mathrm{C}$ in the exon 8 was observed in 5 patients and 4 controls. Another polymorphism of $1038 \mathrm{~A} \geq \mathrm{G}$ in the exon 8 was observed in 7 patients and 4 controls. Both polymorphisms do not cause amino acid substitution (A318A \& L346L) (Fig. 2A-B).

Genotype/phenotype correlation. We found 5 patients with mutations in both NPHS1 and NPHS2 genes. However, all of these are known polymorphisms with no amino acid substitution (same sense mutation, Table 5). Patients 10 and 11 are homozygous for $\mathrm{V} 763 \mathrm{~V}$ in the $\mathrm{NPHS1}$ gene and heterozygous for L346L in the NPHS2 gene; Patient 12 is heterozygous for V763V in the NPHS1 gene and homozygous for A318A in the NPHS2 gene. This patient is steroid resistant. Patient 13 is heterozygous for T741T in the NPHS1 gene and homozygous for A318A in the NPHS2 gene. Finally patient 14 is homozygous for S1105S in the NPHS1 gene and heterozygous for L346L in the NPHS2 gene. Four of patients (patient 10, 11, 13 and 14) are sensitive to standard steroid treatment strategy. No correlation of genotype/phenotype was found among them in NPHS1 and NPHS2 gene.

Genotypic and allelic frequencies. There was no significant difference in the genotypic and allelic frequencies of the $2223 \mathrm{C}>\mathrm{T}, 2289 \mathrm{C}>\mathrm{T}, 3315 \mathrm{G}>\mathrm{A}$ polymorphisms in the NPHS1 gene or the $954 \mathrm{~T}>\mathrm{C}, 1038 \mathrm{~A}>\mathrm{G}$ polymorphisms in the NPHS2 gene between patients and controls (Table 6).

Table 5. Clinical data of 5 NS patients carrying both NPHS1 and NPHS2 mutation

\begin{tabular}{|c|c|c|c|c|c|c|c|c|c|c|c|}
\hline \multirow[b]{2}{*}{ Patient } & \multirow[b]{2}{*}{ Gender } & \multirow[b]{2}{*}{$\begin{array}{l}\text { Age } \\
\text { (years) }\end{array}$} & \multirow[b]{2}{*}{$\begin{array}{l}\text { Age at onset } \\
\text { (years) }\end{array}$} & \multirow[b]{2}{*}{$\begin{array}{l}\text { Proteinuria } \\
\text { (g/24h) }\end{array}$} & \multirow[b]{2}{*}{$\begin{array}{l}\text { Serum creatinine } \\
\qquad(\mu \mathrm{mol} / \mathrm{L})\end{array}$} & \multirow[b]{2}{*}{$\begin{array}{c}\text { BUN } \\
(\mathrm{mmol} / \mathrm{L})\end{array}$} & \multirow[b]{2}{*}{$\mathrm{C}_{3} \mathrm{mg} / \mathrm{dl}$} & \multirow[b]{2}{*}{ SS/SR } & \multirow[b]{2}{*}{ Renal biopsy } & \multicolumn{2}{|c|}{ Mutation } \\
\hline & & & & & & & & & & NPHSI & NPHS2 \\
\hline 10 & F & 8.5 & 6.3 & 5.57 & 102.6 & 6.46 & 90.3 & SS & ND & V763V (H) & L346L(h) \\
\hline 12 & M & 7.2 & 4.1 & 3.84 & 115.6 & 9.67 & 114.8 & SR & MCNS & V763V (h) & $\mathrm{A} 318 \mathrm{~A}(\mathrm{H})$ \\
\hline 13 & M & 11.7 & 6.5 & 3.29 & 96.2 & 5.81 & 81.7 & SS & ND & T741T(h) & $\mathrm{A} 318 \mathrm{~A}(\mathrm{H})$ \\
\hline 14 & M & 12.8 & 10.8 & 6.23 & 127.7 & 5.53 & 143.6 & SS & ND & $\mathrm{S} 1105 \mathrm{~S}(\mathrm{H})$ & L346L(h) \\
\hline
\end{tabular}

$\mathrm{H}$, homozygous; h, heterozygous; ND, not determined; MCNS, minimal change nephrotic syndrome; BUN, serum urea nitrogen; C3, complement C3; SS, steroid sensitive; SR, steroid resistant. 
Table 6. Genotypic and allelic frequencies of 5 polymorphisms in 60 patients and 30 controls

\begin{tabular}{|c|c|c|c|c|}
\hline & $\begin{array}{l}\text { Patients } \\
(n=60)\end{array}$ & $\begin{array}{l}\text { Controls } \\
(n=30)\end{array}$ & $\chi^{2}$ & $p$ \\
\hline \multicolumn{5}{|c|}{$2223 \mathrm{C}>\mathrm{T}$ of NPHS1 } \\
\hline \multicolumn{5}{|c|}{ Genotype } \\
\hline $\mathrm{CC}$ & $51(85 \%)$ & $26(87 \%)$ & 0.000 & 1.000 \\
\hline $\mathrm{CT}$ & $9(15 \%)$ & $4(13 \%)$ & 0.000 & 1.000 \\
\hline TT & $0(0 \%)$ & $0(0 \%)$ & - & - \\
\hline \multicolumn{5}{|l|}{ Allele } \\
\hline $\mathrm{C}$ & 0.93 & 0.94 & 0.000 & 1.000 \\
\hline $\mathrm{T}$ & 0.07 & 0.06 & 0.000 & 1.000 \\
\hline \multicolumn{5}{|c|}{$2289 \mathrm{C}>\mathrm{T}$ of NPHS 1} \\
\hline \multicolumn{5}{|c|}{ Genotype } \\
\hline $\mathrm{CC}$ & $44(73 \%)$ & $25(83 \%)$ & 1.118 & 0.290 \\
\hline $\mathrm{CT}$ & $10(17 \%)$ & $3(10 \%)$ & 0.281 & 0.596 \\
\hline TT & $6(10 \%)$ & $2(7 \%)$ & 0.017 & 0.896 \\
\hline \multicolumn{5}{|l|}{ Allele } \\
\hline $\mathrm{C}$ & 0.82 & 0.88 & 1.315 & 0.251 \\
\hline $\mathrm{T}$ & 0.18 & 0.12 & 1.315 & 0.251 \\
\hline \multicolumn{5}{|c|}{$3315 \mathrm{G}>\mathrm{A}$ of NPHS 1} \\
\hline \multicolumn{5}{|c|}{ Genotype } \\
\hline GG & $58(97 \%)$ & $28(94 \%)$ & 0.033 & 0.856 \\
\hline GA & $0(0 \%)$ & $0(0 \%)$ & - & - \\
\hline AA & $2(3 \%)$ & $2(6 \%)$ & 0.033 & 0.856 \\
\hline \multicolumn{5}{|l|}{ Allele } \\
\hline $\mathrm{G}$ & 0.97 & 0.94 & 0.409 & 0.523 \\
\hline A & 0.03 & 0.06 & 0.409 & 0.523 \\
\hline \multicolumn{5}{|c|}{$954 \mathrm{~T}>\mathrm{C}$ of NPHS2 } \\
\hline \multicolumn{5}{|c|}{ Genotype } \\
\hline TT & $55(92 \%)$ & $26(87 \%)$ & 0.139 & 0.709 \\
\hline $\mathrm{TC}$ & $0(0 \%)$ & $2(7 \%)$ & - & 0.109 \\
\hline $\mathrm{CC}$ & $5(8 \%)$ & $2(7 \%)$ & 0.000 & 1.000 \\
\hline \multicolumn{5}{|l|}{ Allele } \\
\hline $\mathrm{T}$ & 0.92 & 0.90 & 0.137 & 0.711 \\
\hline $\mathrm{C}$ & 0.08 & 0.10 & 0.137 & 0.711 \\
\hline \multicolumn{5}{|c|}{$1038 \mathrm{~A}>\mathrm{G}$ of NPHS2 } \\
\hline \multicolumn{5}{|c|}{ Genotype } \\
\hline AA & $53(88 \%)$ & $26(87 \%)$ & 0.000 & 1.000 \\
\hline $\mathrm{AG}$ & $7(12 \%)$ & $2(7 \%)$ & 0.139 & 0.709 \\
\hline GG & $0(0 \%)$ & $2(7 \%)$ & - & 0.109 \\
\hline \multicolumn{5}{|l|}{ Allele } \\
\hline A & 0.94 & 0.90 & 0.508 & 0.476 \\
\hline G & 0.06 & 0.10 & 0.508 & 0.476 \\
\hline
\end{tabular}

\section{DISCUSSION}

In this study we investigated the possible role of the major slit diaphragm proteins, nephrin and podocin, by analyzing the structure of their coding gene in patients with sporadic nephrotic syndrome in childhood. One novel missense mutation (Q453R), 1 known missense mutation (R800C), and 3 known polymorphisms (T741T, V763V, S1105S) in the NPHS1 gene were identified. Additionally 2 novel missense mutations (E188D, S206I), 1 novel nonsense mutation (Glu237STOP), and 2 known polymorphisms (A318A, L346L) in the NPHS2 gene were found in 38 SSNS and 22 SRNS patients.

There are several studies reporting mutations in both NPHS1 and NPHS2 gene in congenital FSGS. Koziell (11) et al. first reported mutations both in NPHS1 \& NPHS2 in 4 individuals from 3 different families with congenital FSGS. They found an overlap in the NPHS1/NPHS2 mutation spectrum with the characterization of a unique di-genic inheritance of NPHS1 and NPHS2 mutations, which results in a 'tri- allelic' hit and appear to modify the phenotype from CNF to one of congenital FSGS. Caridi et al. (16) reported one patient with heterozygous NPHS1 mutation and a homozygous NPHS2 mutation (R229Q). Schultheiss et al. (17) reported 5 patients with combined mutations in the NPHS1 and NPHS2 genes, but absence of evident phenotype/genotype correlation was found in their study. In present study no correlation of genotype/phenotype was found either in the NPHSI and NPHS2 genes.

Some studies have showed that polymorphisms, even when not result in amino acid substitutions, might cause phenotypic variations either by affecting the structural of the mRNA or by inactivating genes through the change in gene splicing machinery to skip the mutant exons (18). This possibility remains to be investigated in our patients in the future. In 23 Chinese sporadic SRNS patients by Yu et al. (18), 1 case of heterozygous missense mutation and 7 polymorphisms of the NPHS2 gene in some patients and controls were reported. In addition, no significant differences in genotypic and allelic frequencies of these polymorphisms between patients and controls were found which was similar to our present study.

European and North American studies $(3,16,19)$ of large cohorts of SRNS patients revealed a detection rate of homozygous or compound heterozygous NPHS2 mutations of $38 \%$ and $26 \%$, respectively, in patients with familial SRNS and of $6-19 \%$ in sporadic cases. The percentage of patients with only one NPHS2 mutation was low, being only $2-3 \%$. Both studies $(16,19)$ confirm that FSGS in patients with two pathogenic NPHS2 mutations is generally characterized by early-onset, resistance to standard steroid treatment, and a reduced risk of FSGS recurrence after kidney transplantation. Ruf et al. (20) reported in 26 NS patients carrying compound heterozygous mutations (double mutations) in the NPHS2 gene. Of them, 22 patients showed steroid resistance and 11 patients developed ESRD. In contrast to this, in 9 patients with single heterozygous mutation in the NPHS2 gene, 4 patients showed steroid response, and only 1 patient developed ESRD after 8 y of the onset. Caridi et al. (21) described an infantile variant in 2 families (3 patients) from Turkey, characterized by homozygosity of a complex haplotype, in which 2 NPHS2 mutations (P20L \& R168H) are present. The patients reported developed NS within the first 6 mo of life with strict resistance to drugs and a histologic background of FSGS. The very early onset of proteinuria might mimic severe NS patients such as congenital NS of the Finnish type. These results imply that, while compound heterozygous mutations of gene(s) is associated with strictly steroid/cyclosporine resistance, patients with single mutation are more likely to respond to therapy and may have a better long-term outcome than patients with compound mutations (22). In present study, 1 patient carried compound mutations in NPHS1 gene (T741T in exon 17, heterozygous and R800C in exon 18, heterozygous), and was steroid resistant. No differences were found in symptom severity or response to drug therapy in this patient and the 2 others with the R800C mutation. Normally most cases of monogenic diseases are heterozygous, because homozygous or compound heterozygous states might be either lethal or associated with a 
more severe phenotype than in single heterozygotes $(23,24)$. This is also the case in common multigenic disorders.

According to our results and others (25), screening the newly diagnosed patients with sporadic NS, especially with SRNS, for the presence of possible NPHS2 mutations is evidently necessary. It might be also meaningful to screen the mutation of NPHS1 in SRNS. Differences in clinical findings of patients with or without NPHS1 and/or NPHS2 mutation are not always distinct, so the genetic analysis might be valuable to separate these two entities as early as possible to avoiding unnecessary steroid therapy, because missense and nonsense mutations as these may be present in sporadic SRNS patients without a familial history of renal disease.

Acknowledgments. The authors thank Wu Yedong, Sheng Zheng and Yu Zhongsheng for their excellent technical assistance, and Dr Xia Yonghui, Huang Yaping for many helpful clinical advice. The authors are also grateful for Dr Wu Dehua and Zhang Chong for providing control kidney materials to us. Finally the authors thank Timo Pikkarainen, who works in Division of Matrix, MBB, Karolinska Institutet of Sweden, for his generous help about the correction of English language grammar and usage in our manuscript.

\section{REFERENCES}

1. Hodson EM, , Habashy D, Craig JC 2006 Interventions for idiopathic steroidresistant nephrotic syndrome in children. Cochrane Database Syst Rev Apr 19(2):CD003594.

2. Kim JS, Bellew CA, Silverstein DM, Aviles DH, Boineau FG, Vehaskari VM 2005 High incidence of initial and late steroid resistance in childhood nephrotic syndrome. Kidney Int 68:1275-1281

3. Fuchshuber A, Gribouval O, Ronner V, Kroiss S, Karle S, Brandis M, Hildebrandt F 2001 Clinical and genetic evaluation of familial steroid- responsive nephrotic syndrome in childhood. J Am Soc Nephrol 12:374-378

4. Kestila M, Lenkkeri U, Mannikko M, Lamerdin J, McCready P, Putaala H, Ruotsalainen V, Morita T, Nissinen M, Herva R, Kashtan CE, Peltonen L, Holmberg C, Olsen A, Tryggvason K 1998 Positionally cloned gene for a novel glomerular protein-nephrin-is mutated in congenital nephrotic syndrome. Mol Cell 1:575-582

5. Boute N, Gribouval O, Roselli S, Benessy F, Lee H, Fuchshuber A, Dahan K, Gubler MC, Niaudet P, Antignac C 2000 NPHS2, encoding the glomerular protein podocin, is mutated in autosomal recessive steroid-resistant nephrotic syndrome. Nat Genet 24:349-354

6. Kaplan JM, Kim SH, North KN, Rennke H, Correia LA, Tong HQ, Mathis BJ, Rodriguez-Perez JC, Allen PG, Beggs AH, Pollak MR 2000 Mutations in ACTN4, encoding alpha-actinin-4, cause familial focal segmental glomerulosclerosis. Nat Genet 24:251-256

7. Orloff MS, Iyengar SK, Winkler CA, Goddard KA, Dart RA, Ahuja TS, Mokrzycki M, Briggs WA, Korbet SM, Kimmel PL, Simon EE, Trachtman H, Vlahov D, Michel DM, Berns JS, Smith MC, Schelling JR, Sedor JR, Kopp JB 2005 Variants in the Wilms' tumor gene are associated with focal segmental glomerulosclerosis in the African American population. Physiol Genomics 21:212-221

8. Winn MP, Conlon PJ, Lynn KL, Farrington MK, Creazzo T, Hawkins AF, Daskalakis N, Kwan SY, Ebersviller S, Burchette JL, Pericak-Vance MA, Howell DN, Vance JM, Rosenberg PB 2005 A mutation in the TRPC6 cation channel causes familial focal segmental glomerulosclerosis. Science 308:1801-1804

9. Lahdenkari AT, Kestila M, Holmberg C, Koskimies O, Jalanko H 2004 Nephrin gene (NPHS1) in patients with minimal change nephrotic syndrome (MCNS). Kidney Int 65:1856-1863

10. Beltcheva O, Martin P, Lenkkeri U, Tryggvason K 2001 Mutation spectrum in the nephrin gene (NPHS1) in congenital nephrotic syndrome. Hum Mutat $17: 368-373$

11. Koziell A, Grech V, Hussain S, Lee G, Lenkkeri U, Tryggvason K, Scambler P 2002 Genotype/phenotype correlations of NPHS1 and NPHS2 mutations in nephrotic syndrome advocate a functional inter-relationship in glomerular filtration. Hum Mol Genet 11:379-388

12. Karle SM, Uetz B, Ronner V, Glaeser L, Hildebrandt F, Fuchshuber A 2002 Nove mutations in NPHS2 detected in both familial and sporadic steroid- resistant nephrotic syndrome. J Am Soc Nephrol 13:388-393

13. Caridi G, Bertelli R, Carrea A, Di Duca M, Catarsi P, Artero M, Carraro M, Zennaro C, Candiano G, Musante L, Seri M, Ginevri F, Perfumo F, Ghiggeri GM 2001 Prevalence, genetics, and clinical features of patients carrying podocin mutations in steroid-resistant nonfamilial focal segmental glomerulosclerosis. J Am Soc Nephrol 12:2742-2746

14. Winn MP 2002 Not all in the family: mutations of podocin in sporadic steroidresistant nephrotic syndrome. J Am Soc Nephrol 13:577-579

15. Lahdenkari AT, Suvanto M, Kajantie E, Koskimies O, Kestila M, Jalanko H 2005 Clinical features and outcome of childhood minimal change nephrotic syndrome: is genetics involved? Pediatr Nephrol 20:1073-1080

16. Caridi G, Bertelli R, Di Duca M, Dagnino M, Emma F, Onetti Muda A, Scolari F, Miglietti N, Mazzucco G, Murer L, Carrea A, Massella L, Rizzoni G, Perfumo F, Ghiggeri GM 2003 Broadening the spectrum of diseases related to podocin mutations. J Am Soc Nephrol 14:1278-1286

17. Schultheiss M, Ruf RG, Mucha BE, Wiggins R, Fuchshuber A, Lichtenberger A, Hildebrandt F 2004 No evidence for genotype/phenotype correlation in NPHS1 and NPHS2 mutations. Pediatr Nephrol 19:1340-1348

18. Yu Z, Ding J, Huang J, Yao Y, Xiao H, Zhang J, Liu J, Yang J 2005 Mutations in NPHS2 in sporadic steroid-resistant nephrotic syndrome in Chinese children. Nephrol Dial Transplant 20:902-908

19. Weber S, Gribouval O, Esquivel EL, Moriniere V, Tete MJ, Legendre C, Niaudet P, Antignac C 2004 NPHS2 mutation analysis shows genetic heterogeneity of steroidresistant nephrotic syndrome and low post-transplant recurrence. Kidney Int 66:571579

20. Ruf RG, Lichtenberger A, Karle SM, Haas JP, Anacleto FE, Schultheiss M, Zalewski I Imm A, Ruf EM, Mucha B, Bagga A, Neuhaus T, Fuchshuber A, Bakkaloglu A, Hildebrandt F Arbeitsgemeinschaft Fur Padiatrische Nephrologie Study Group 2004 Patients with mutations in NPHS2 (podocin) do not respond to standard steroid treatment of nephrotic syndrome. J Am Soc Nephrol 15:722 732.

21. Caridi G, Berdeli A, Dagnino M, Di Duca M, Mir S, Cura A, Ravazzolo R, Ghiggeri GM 2004 Infantile steroid-resistant nephrotic syndrome associated with double homozygous mutations of podocin. Am J Kidney Dis 43:727-732

22. Caridi G, Bertelli R, Perfumo F, Ghiggeri GM 2004 Heterozygous NPHS1 or NPHS2 mutations in responsive nephrotic syndrome and the multifactorial origin of proteinuria. Kidney Int 66:1715-1716

23. de Bernabé DB, van Bokhoven H, van Beusekom E, Van den Akker W, Kant S, Dobyns WB, Cormand B, Currier S, Hamel B, Talim B, Topaloglu H, Brunner HG 2003 A homozygous nonsense mutation in the Fukutin gene causes a WalkerWarburg syndrome phenotype. J Med Genet 40:845-848

24. Weatherall DJ 2000 Single gene disorders or complex traits: lessons from the thalassaemias and other monogenic diseases. BMJ 321:1117-1120

25. Ekim M, Ozcakar ZB, Acar B, Yuksel S, Yalcnkaya F, Tulunay O, Ensari A, Erbay B 2004 Three siblings with steroid-resistant nephrotic syndrome: new NPHS2 mutations in a Turkish family. Am J Kidney Dis 44:E22-E24 